\title{
Development of vaccine for "hepatitis C" (Papaya mosaic virus as an expression vector for foreign epitopes) Varsha Raja* and MG AbouHaidar
}

Address: Laboratory of Virology, Department of Botany, University of Toronto, Toronto, Canada

* Corresponding author

from 2006 International Meeting of The Institute of Human Virology

Baltimore, USA. 17-2I November, 2006

Published: 21 December 2006

Retrovirology 2006, 3(Suppl I):P52 doi:I0.I I86/I742-4690-3-SI-P52

(C) 2006 Raja and AbouHaidar; licensee BioMed Central Ltd.

This work focuses on the use of Papaya Mosaic Virus (PMV), a plus-sense RNA potexvirus that forms rodshaped particles, for high yield production of Hepatitis C virus (HCV) epitopes. We produced PMV clones in which an epitope from the HCV core gene was inserted into the $\mathrm{N}$-terminus of the PMV capsid gene. Furthermore the infectivity and functionality of these clones and weather they retained HCV sequences post infection was assayed. The preliminary results indicate that the clones are weakly infectious and in those cases that infections do occur and lesions are produced, it seems that the HCV sequence is lost. This could be due to homologues recombination in clones containing two copies of the capsid gene. Future work will focus on optimization of foreign inserts through further work on PMV clones containing one copy of the capsid gene in which the HCV sequence has been inserted. 